\title{
Distanciation and the Recontextualization of Space: Finding One's Way in a Small Western Community
}

In the 1990s, the city of McCall, Idaho, and the surrounding region implemented the Rural Addressing System. The system assigned a name to every street and a number to every house and erected visible signage for both. Although a seemingly minor bureaucratic operation, the Rural Addressing System is a concrete example of Anthony Giddens's concept of space distanciation, and as such, it is a significant component of modernity and globalization. By investigating the impact of the Rural Addressing System on this region-particularly on the ways in which people give directions and think about space there - this article sheds light on how abstract processes such as modernization and globalization actually manifest in everyday life, the effects of those processes, and how people respond to them.

\section{Introduction}

Like many other regions throughout the Intermountain West, the Payette Lakes area of west-central Idaho has undergone dramatic social, cultural, and economic changes since the 1960s. These changes entail shifting demographics; substantial increases in housing and development; and a transition from industrial, extraction-based industries such as logging, ranching, and mining to postindustrial, service-based, and globalized economies based on tourism and recreation. Part and parcel of the socioeconomic changes in the Payette Lakes area is a reconfiguration of local space on the part of officials by means of a technology called the Rural Addressing System, which was implemented between 1990 and 1994. Prior to this time, most local streets did not have visible signage, and houses did not have numbers. Mail was (and still is) delivered centrally to post office boxes, and 911 emergency services did not exist. The Rural Addressing System (also referred to as RAS) erected visible street signs and assigned house numbers; it thus constituted a reorganization of space at city and county levels. ${ }^{1}$ I am concerned here with detailing this spatial transformation as a phenomenon of modernization and exploring its relationship to constructions of local identity.

Lisa Gabbert is Assistant Professor of Folklore and American Studies, Department of English, Utah State University Logan, Utah

Journal of American Folklore 120(476):178-203

Copyright ( $\odot 2007$ by the Board of Trustees of the University of Illinois 
Drawing on social theorist Anthony Giddens's concept of time-space distanciation, this article ethnographically investigates the effects of the Rural Addressing System on the local organization of space by examining wayfinding performances- that is, the giving and receiving of directions in social interaction. Ways of organizing space manifest themselves in wayfinding, offering a useful means by which to examine underlying spatial principles. I argue that the Rural Addressing System is a concrete example of space distanciation, which Giddens claims is intricately connected to modernity and globalization. ${ }^{2}$ Investigating the Rural Addressing System in the Payette Lakes area can thus shed light on how globalizing processes are manifested in everyday life, what the effects of such processes are, and how people respond to them. On the one hand, the Rural Addressing System is a rationalization of space, directly linked to the socioeconomic modernization the area currently is experiencing and indicative of modern forms of technological control and the exercises of power. On the other hand, its effects as manifested in on-the-ground wayfinding practices are far from totalizing or complete. Residents do not use the RAS straightforwardly, and they sometimes avoid using it at all. Rather than the wholesale replacement of "traditional" modes of organizing space with "modern" ones, space distanciation is mediated by interrelated factors such as residential identity and the rhetorical framing of immediate social relationships. These factors are further complicated by desires to establish status and power and even by occasional resistance to perceived ideological domination. Investigating the nature of these contingencies and how they affect people's wayfinding choices offers insight into the unevenness and contradictions of modernity and of the role of the local in processes of globalization.

\section{The Payette Lakes Area: A Changing Context}

Located in the northern tip of Valley County, the Payette Lakes area is a remote, rugged, mountainous area encompassing the village of McCall and its surroundings. McCall itself is small; in 2004, its year-round permanent population was 2,304 (Idaho Department of Commerce and Labor n.d.a), although it is estimated to swell to upwards of 10,000 during the summer and to 20,000 over major holidays such as July 4 (estimates provided by the McCall Chamber of Commerce, City Hall, and McCall Police). The region is flanked on all sides by the Payette National Forest, and the county includes portions of the Frank Church River of No Return Wilderness Area (2.4 million acres), which, along with the adjacent Bitterroot and Gospel-Hump wilderness areas, constitutes the largest tract of wilderness in the continental United States. It is, by any account, a remote and sparsely populated region.

It has always been difficult to make a living in the area. Historically, the region relied on logging and forestry as primary sources of income. The local mill, which existed even before the village was founded in 1889, was owned by the Brown family for much of the twentieth century. The mill employed the majority of the townspeople, while others worked seasonal jobs at the lumber camps in the backcountry, for the Forest Service, or in the private sector. At the same time, however, the Payette Lakes area always has been a place of vacation homes, visitors, tourists, and transients. Wealthy and middle-class residents from Boise, approximately one hundred miles to 
the south, began constructing cabins along the lakeshore not long after the area was settled; the first summer cabin apparently was built in 1906 (Jordan 1961:287 n. 31). These early cabins were used primarily during the summer, as most were not winterized until the 1960s, when winter recreation became more popular. My family, for example, owned one-third of a ramshackle cabin located several hundred yards from the lakeshore, and we came up from Boise for the weekend approximately once a month to hike, swim, or ski, depending on the season. Because of its lakefront property and the fact that it is the largest town within a one-hundred-mile radius, McCall always has been the hub of social life for the region and has catered to middle-class visitors throughout the twentieth century. An early postcard from the town pictures a boat owned by a man named Anneas Wyatt (also known as "Jew's Harp Jack"), which not only hauled logs from one end of Payette Lake to the other but also took passengers on lake tours and served as a place for on-the-water dances from 1900 to 1919 (Cottrell and Ingraham 1987:62). During the first half of the twentieth century, McCall also offered less-refined pleasures, giving it a mildly unruly reputation. Because of its remoteness, gambling, alcohol, and prostitutes were readily available to loggers who came to town on weekends from the backcountry camps to blow off steam. Cottrell and Ingraham's pictorial history of the region, for example, also features a postcard from the "early 1900s" of four women beside a mule. The caption- "Four Queens and a Jack”- alludes to the area's history of card playing (1987:60).

Beginning in the 1960s, however, the socioeconomic structure of the area began to change, as logging decreased in importance and tourism increased. One important sign was the change in ownership of the mill in 1964, when the Brown family sold the mill to the Boise Cascade Corporation. Boise Cascade owned forest land and other mills in towns in the region, such as Cascade, Horseshoe Bend, Emmett, and Council. The transformation from local to multinational ownership of the McCall mill was a significant shift. Additionally, Brundage Ski Mountain opened near McCall in 1961 as the area's first modern, mechanized ski area, and residents revived a moribund winter carnival in 1965 specifically to attract winter visitors. Both of these events signaled the growing importance of winter tourism to the already-established traditional summer season. Further, while only ten new "additions" (tracts of land) were incorporated into the city between 1911 and 1965, beginning in 1971 there was at least one new addition per year. These new additions also indicate the growing importance of tourism to the area, as most of these new developments were for second homes.

In 1977, Boise Cascade closed the McCall mill, signaling the beginning of the deindustrialization and global restructuring of the timber industry. Although many people managed to find work in the other Boise Cascade mills, this process continued regionally with the closing of the Council mill in 1995 and the Horseshoe Bend mill in 1998. The last Boise Cascade regional mills were closed in Emmett and Cascade in 2001. Most of these towns, particularly Council, Horseshoe Bend, and Emmett, have not recovered.

In contrast, McCall's historic identity as a vacation spot has come to play a much more prominent economic role, as the town has sought to reconstruct itself as a des- 
tination resort. During the late 1980s, McCall emerged as an investment site for national developers, particularly San Diego developer Doug Manchester, who has acquired large portions of the town, including the only hotel on the lake. ${ }^{3}$ Development has since skyrocketed. The county secured its reputation on the global stage in 2004 with the opening of Tamarack Ski Resort by French developer Jean-Pierre Boespflug outside the town of Donnelly, some eleven miles to the south. Tamarack markets itself as a "world class ski resort," and over the past year it is rumored to have attracted movie stars such as John Travolta and Meg Ryan. In August 2005, President George W. Bush stayed at Tamarack during one of his holidays away from his normal vacation home in Crawford, Texas, and the area is now regularly featured in travel magazines, including an article in United Airlines' in-flight magazine Skywest under the telling front cover copy, "Authentic Idaho" (Steubner 2006). These events suggest that the Payette Lakes area has cemented its identity as a destination resort, fully entering the postindustrial phase in the development of capital.

These changes are a source of debate and controversy for people who live here. Residents are asking, "Who are we?" and "What kind of place should this be?" As John Tomlinson (1999) notes, in the face of globalization, issues of identity become salient. Development is a constant subject of conversation. Most articles in the local newspaper have to do with development, land use, and applications for new housing developments, as housing costs have increased beyond the means of many people. ${ }^{4}$ Heretofore unheard-of issues such as subsidized housing are current topics of debate, and in 2005 the city imposed a moratorium on proposals for new developments, because its planning and zoning committee was so overwhelmed. Yet despite the changes, social identities do not fall into neat categories of insiders and outsiders, locals and tourists, powerful and marginalized, although such concepts have ideological import and are used in conversation. Because of the area's logging history, for example, there have always been transients here. Those families who have owned cabins for years or who visit on weekends are often considered to be locals, even though they reside elsewhere, and many locals often spend winters in warmer climates to avoid the heavy snow. Only 40 percent of residences in McCall are occupied fulltime, while 60 percent are occupied part-time. Furthermore, many locals have embraced and sought out development, and they are proud that their area is now "on the map." Family land has been sold at profitable sums, and old families are involved with outside developers. In Valley County, 80 percent of the land is publicly owned, and as a result private property rights-including the right to develop-are fiercely protected. Thus, while residents acknowledge the many changes in the area and while many people feel that they are being pushed around by outside interests, just who those outside interests are and how those relations actually map out is quite complex. Yet, as developers have come into this town, the social geography of people's lives has changed dramatically. Not only has wayfinding - the simple but essential act of getting from place to place-become problematic, but it also serves as a sticking point in people's daily life. While all of the social life in the Payette Lakes area does not turn on wayfinding, the practice is important in the lives of the people there. It is one of the most constant and direct ways in which they experience social change. 


\section{Space Distanciation and the Globalization of Modernity}

One of the many changes the town of McCall has seen recently was the implementation between 1990 and 1994 of the Rural Addressing System, which required street signs to be erected on streets and house numbers to be placed on residential houses. This system standardizes city and county addresses and implements the address system used in most other parts of the United States. Although an apparently innocent bureaucratic operation, the Rural Addressing System is a concrete example of what Giddens (1990) calls space distanciation, a process that is, in Giddens's view, a significant component of modernity.

Space distanciation is part of a broader concept called time-space distanciation that Giddens developed as part of his theory of structuration and later elaborated as a primary element of his theories on modernity and globalization. Giddens succinctly defines time-space distanciation as "the conditions under which time and space are organized so as to connect presence and absence" (1990:14). What he means by this is that time-space distanciation separates or "stretches" relations of time and space so that they no longer adhere to an actual locale. In Giddens's model, prior to distanciation (i.e., in so-called "premodern" societies), time and space are intricately interconnected. A knowledge of time in premodern societies, for example, depended on where one was. Time, therefore, was linked to locale, and understanding either time or space depended on the construction of their relation to each other and on specific local knowledges. In Giddens's words, time and space were "attached to place" or "embedded" (1990:17-20).

For Giddens, time-space distanciation entails "emptying” time and space and separating them from each other. Giddens suggests that mechanical clocks and the worldwide standardization of calendars functioned to empty time, largely through standardization. The emptying of space entails the separation of space from place, "fostering relations between 'absent' others, locationally distant from any given situation of face-to-face interaction" (1990:18). Although standardized measurement is a way to empty space, Giddens says that tearing space away from place depends on two factors. First is "allowing for the representation of space without reference to a privileged locale which forms a distinct vantage-point.” A lack of perspective-in other words, a bird's eye view-is one way in which space is separated from place. The second factor that allows the distanciation of space from locale is those processes "making possible the substitutability of different spatial units," such as procedures used by mapping and cartography (1990:19).

Time-space distanciation provides the conditions for what Giddens identifies as the "disembedding" of social relations, in which relations are lifted out of their "local contexts of interaction and ... restructur[ed] across indefinite spans of time-space" (1990:21). In other words, the emptying of time and space provides opportunities for the recontextualization of entire social systems, removing them from their basis in face-to-face interaction and fostering relations between people of different settings. "Symbolic tokens" that do not depend on the qualities of the group handing them, such as money, are one such mechanism. Another mechanism is "expert systems" such as airline travel, in which people must depend on the technological expertise of 
strangers. The flip side of all this is the process of "re-embedding," in which social relations are reattached in new conditions. It is in the process of re-embedding that Giddens pins his hopes for a humane modernity.

The concept of time-space distanciation specifically was developed by Giddens and has widespread currency in social theory. The idea that "being modern" somehow entails a perception of fundamentally breaking with the past, in part through the reordering of time and space, however, is essential to understanding what is meant by modernity in classical scholarly constructs; indeed, the notion of time as progressive, linear, and future-oriented is explicit in modernity's tropes. "Modern" conceptions of time and space as, for example, infinite, objective, and abstract generally are considered to be the product of late-Renaissance and Enlightenment thought, differing greatly when compared with medieval constructions of time and space, which were based in religious traditions (Fabian 1983). This rationalization of time and space in Europe during the seventeenth century is linked to other historic sociocultural shifts associated with modernity, such as changing conceptions of marriage and the family, the rise of the nation-state, individualism, secularization, functional specialization, bureaucracy, industrial capitalism and wage labor, and increased divisions between public and private spheres. Jonas Frykman and Orvar Löfgren (1987), for example, link the internalization of mechanized, standardized time in Sweden with the rise of the middle class and wage labor in the late eighteenth and early nineteenth centuries; likewise, David Harvey (1990) identifies the chronometer as a device that helped to reconceptualize traditional, religious time as having a past and a future, and he links this newer conception of time with growing ideas about profit. Additionally, Harvey links the rise of perspectivism (the representation of the world from the viewpoint of the objective individual eye) in late-Renaissance mapmaking and the visual arts to emerging ideas about individualism, the nation, and ultimately the notion that space could be freely traded (i.e., land as private property).

The appreciation of the importance of space for social theory has increased in recent years. According to Edward Soja (1989), for example, the analysis of time in the construction of social life tended to be privileged until approximately the 1980s, while space was treated as static, neutral, transparent, and hence theoretically uninteresting. ${ }^{5}$ In other words, space generally was not considered as active or motivated; it was a ground to the figure of time. With the translation and increasing influence of spatial theorists such as Henri Lefebvre, however, space has come to be seen as intricately interconnected to human activity and therefore as implicated in politics, ideology, and power relations. Coming from a Marxist perspective, Lefebvre suggested that space could be a kind of social product: "The production of space can be likened to the production of any given particular type of merchandise" (1976:31; see also Lefebvre 1991). In other words, Lefebvre was one of the first theorists to consider that space was produced rather than merely something already in existence, and as a result, the mode of its relations of production became essential. He later writes, "To speak of 'producing space' sounds bizarre, so great is the sway still held by the idea that empty space is prior to whatever ends up filling it" (1991:15). Building upon the idea that space is produced and that that production has consequences, other influential theorists such as Michel Foucault and Michel de Certeau have since ex- 
plored the various ways in which the (re)organization of space is implicated in narratives of modernity and configurations of power. Foucault ([1977] 1995) considered space as a container for power, outlining both the ways in which space is organized and rationalized for purposes of modern surveillance and how bodies are disciplined through spatial microphysics. Among others, de Certeau (1984) introduces a note of agency and resistance into Foucault's picture-because, as Nigel Thrift dryly notes, "[i]n Foucault country, it always seems to be raining" (2000:269)_illustrating, for example, how people might resist the relentless rationalization of city space by using their own spatial tactics. And as the literature on modernity has grown, so too has research on space and place, as these terms are implicated in modernity's frameworks. This literature includes Marxist-feminist deconstructions (Haraway [1997] 2002; Massey 1994; McDowell 1999), studies of the relations between the built landscape and identity politics (Norkunas 1993), sense of place and place-attachment studies (Allen and Schlereth 1990; Altman and Low 1992; Ryden 1993; Tuan 1974, 1977; for a review and critique of this literature, see also Wilson 2000), performance-oriented approaches (Feld and Basso 1996; Johnstone 1990), essays deterritorializing culture and identity (Appadurai 1986, 1988a, 1988b; Bestor 2003; Gupta and Ferguson 1997, especially Malkki's essay in that volume; Halpert 1947; Kaplan and Pease 1993; Radway 1999; Scholte 2000; Shuman and Briggs 1993), works of critical regionalism (Heer 1996; Hufford 2002), and the anthropology of space and place (Low and LawrenceZúñiga 2003).

Because modernity and globalization are interrelated topics, the analysis of space also has become important for thinking about globalization. Propelled by technology, media, and the Internet, the reconfiguration of time and space to link presence and absence across conventional local and national boundaries has become a primary component in theories of globalization-a process that Giddens considers not as something entirely new but rather as the globalization of modernity. In an essay summarizing the field, William Robinson states that, although there are many theories about globalization, scholars in this area generally agree that "economic and cultural relations ... 'stretch' across space and ... reduce the factor of time in ways that were previously unimaginable" (2003:354). Robinson places Giddens's theory of time-space distanciation alongside related notions (such as David Harvey's "timespace compression" and Manuel Castells's idea of simultaneous networks of social relations) as various ways of describing globalization's key features. Although he does not subscribe to the idea himself, Robinson writes that some globalization theorists "have seen in Giddens' general theory of time-space distanciation not only a logical premise for globalization theory but, indeed, an alternative foundation for social theory itself" (2003:357). For some, the (re)organization of time and space within contexts of globalization has become the fundamental unit of analysis in understanding "social life" rather than "society." That is, while society generally has been the fundamental unit of analysis for the social sciences, some argue that the analysis of the social life of time and space now is more important. For example, the restructuring of time-space relations has profound implications for representations of identity, particularly identities based on territory.

Yet, as scholars have continued to explore modernity as a global phenomenon, they 
also have come to recognize that modernity is not a one-size-fits-all model. The social and cultural changes associated with modernity are not historically uniform, and they are not experienced in the same manner by all people. Modernity, in other words, cannot be explained as a simple, one-way hegemonic and homogenizing process exported from the "the West" to "the rest." People respond to and engage with processes of modernization in differing ways, not only resisting, appropriating, and transforming modernization for their own purposes but also transforming those processes themselves (Appadurai 1996; Hall et al. 1996; Heelas, Lash, and Morris 1996; Tomlinson 2003). Importantly, globalizing tendencies toward hegemony and homogeneity provoke counterreactions of resistance, such as a renewed emphasis on locality and tradition (Robins 2003; Robertson 1995). Giddens himself acknowledges that time-space distanciation is not a fully articulated reality but rather provokes oppositional movements, while Tomlinson notes that "there is always a 'push-and-pull' between 'disembedding forces' of [globalizing modernity] and countervailing 'reembedding forces' coming from localities" (1999; quoted in Foster 2002:241). Thus, scholars have sought to pluralize modernity as a way of challenging the notion that modernity describes a singular, monolithic process or experience. The concept of "multiple modernities" (Eisenstadt 2000; Göle 2000; Kaviraj 2000; see also Del Negro 2004) or "comparative modernities" (Foster 2002) illustrates the idea that modernity is culturally and historically contingent, and these scholars have called for closer investigations of its dialectical tendencies and contradictions as they emerge and are negotiated in lived experience (Knauft 2002).

With these issues in mind, this article seeks to understand how space distanciation actually occurs in social life. What are its effects on real people, and how do they respond to it? How do their responses challenge given ideas about distanciation and related concepts? In attempting to answer these questions, I draw on ethnographic fieldwork and interviews that I conducted in McCall in 2000 and 2001. The research explored relations among landscape, folklore, and social change, and I returned for follow-up fieldwork during the summer of 2005 in order to document actual wayfinding practices. Foster (2002) suggests that ethnographically investigating the backand-forth negotiation inherent in disembedding and re-embedding processes is one way to investigate modernity comparatively. Studies of comparative modernities usually involve the analysis of modernization in developing countries; going against this trend, this project seeks to decenter ethnocentric ideas of modernity by investigating space distanciation in the United States, thus debunking the notion that this country is already "beyond" such issues. Investigating the Rural Addressing System as a mechanism for disembedding space, the effects of this mechanism, and the ways in which residents respond to it therefore constitutes a case study of how the apparatuses of modernity and globalization actually work. ${ }^{6}$

\section{Disembedding Space: The Rural Addressing System}

Aside from the downtown and the houses along the rural routes, prior to the late 1980s many parts of the Payette Lakes area did not have street signs posted on the streets and the houses there did not have house numbers. Street signs and numbers 
were unnecessary, because most of the mail for permanent residents was delivered to post office boxes at the central post office, while part-time cabins were devoid of service. ${ }^{7}$ While roads and streets did have formal names that could be found on plats in the county assessor's office, due to the lack of signage most people did not know what these thoroughfares were called.

Since the area lacked a general system of street signs and house numbers, the way in which people gave directions was by necessity based on local landmarks, visible and invisible. Prominent buildings such as the high school, Shore Lodge (a local hotel), Franklin Lumber, the Forest Service, and the post office were the most common. When appropriate, old buildings that no longer exist, such as the Chicken Roost (an old bar and dance hall), were used as well. Other landmarks include the residences of well-known people such as the Browns and more immediate landscape features such as hills, curves, and turns.

Wayfinding methods such as giving and receiving directions help people move about and make sense of their surroundings. Wayfinding methods therefore are a useful tool for comprehending how space is emically organized and understood; in this case, lacking visible street signs and house numbers, local space was organized according to visible local landmarks, immediate social relationships, and historical knowledge. This method of giving directions is not unique to the Payette Lakes area; it is common in many rural regions (Allen 1990; Gaffin 1994). One woman I interviewed, Sheila, ${ }^{8}$ explained how it worked:

Like, you don't have signs on the street.

You don't say, "Well, it's by Spruce Street."

I don't know where the hell "Spruce Street" is!

You know, we didn't get numbers until like four years agoand they didn't give names until about eight years ago, and so we say it's by so-and-so and da-da-da-da.

And so you related like a verbal history of where you wanted to go to how you get there-instead of numbers. ${ }^{9}$

She continued by imitating a hypothetical conversation:

You'd say, "Well, no, it's not by that, it's by the old schoolhouse" ... "Oh, you mean by Adolf Heinrich's?"-

"Yeah! You go out that road, you go out Adolf's road and you go there."

Cause, you couldn't say, "Well, it's at Boydstun [Street], at 8680."

You couldn't say it.

You had to give the clearyou had to give the closest point.

It's like hiking in the woods. You don't say, “Oh gee, here's my GPS [Geographical Positioning System]. It's GPS-something."

Basically ... you say,

"You'll hit a rock and there's a big crack in it. 
There's a tree bending over to the side with a big slash—a blaze on it and take right about fifty feet."

That's how you related to where people lived and how they went and what it was.

Thus, in the Payette Lakes area, prior to the late 1980s the organizing principles undergirding wayfinding were based on experientiality, historical knowledge, and networks of localized, immediate social relationships. Clearly, the organization of space was embedded in locale to a significant degree.

In 1990, Valley County adopted the Rural Addressing Ordinance, which mandated that the county government implement the Rural Addressing System in unincorporated areas. In 1994, the city of McCall adopted Ordinance 660, which did the same for the city. ${ }^{10}$ The Rural Addressing System assigns each street and road a name and each house a number and then erects physical signs for them. My family's cabin was located on an unnamed dirt road approximately one and a half miles north of town. Before RAS, people were able to find the cabin because it had a wooden family sign nailed to a tree by the highway, a practice typical of the area. One weekend we arrived at the cabin to discover a shiny, new street sign for our dirt road; we apparently now were located on "Squirrel Lane," which we found amusing at the time because it was so obviously arbitrary. A house number soon followed.

The Rural Addressing System is a disembedding mechanism for space, exactly conforming to Giddens's description of how space is dislocated from place. It is not contingent upon any kind of local knowledge for understanding. It replicates the nationwide system of street names and house numbers found in most other areas, linking the Payette Lakes area with other places throughout the nation through standardization and making the substitution of one unit for another possible. Further, by installing street signs and house numbers, the RAS not only has reorganized local space, but it has done so according to principles far different from the pre-RAS system. In contrast to the experientiality, historicity, and social relationships undergirding the old system, the organizing principles that underlie the RAS can be described as abstract or unproblematically absolute (Smith and Katz 1993:75) ${ }^{11}$ In other words, the RAS operates on the assumption that this is Euclidean space, space that can be divided into a grid and upon which specific coordinates can be placed. ${ }^{12}$ In Sheila's quotation above, she compares the Rural Addressing System with GPS. In both systems, each location is a unique coordinate, a spot that can be precisely determined. The GPS system does this through satellite positioning while the Rural Addressing System uses street names and house numbers. Both systems presume that all coordinates are available and that the perspective is like that of a map with an omniscient, bird's eye view.

The Rural Addressing System standardizes space in order to improve communication and efficiency. According to County Surveyor Tom Kerr, the Rural Addressing System was implemented to improve community services in the city and county. The police and fire departments and ambulances respond to emergencies more quickly, and such efficiency is one of the positive benefits of standardization. Furthermore, the Rural Addressing System is more democratic than the older, embedded method in the sense that the systematized signs and numbers are out there for all people to 
see; indeed, the influx of visitors unfamiliar with the area was yet another reason for implementing it. Finally, the RAS also aids in the appraisals of property. It is significant that it was enacted between 1990 and 1994, only a few years after developer Doug Manchester began aggressively investing in the town and bringing large numbers of out-of-state visitors and developers to the area. The Rural Addressing System thus coincides with McCall's changing identity and is directly linked to the interests of real estate agents and developers at a time when they began to market McCall as a destination resort and to sell available land. The RAS allows people to get around more easily and facilitates the transfer of property.

The primary reason that the Rural Addressing System improves efficiency is because, by dividing space into a grid, it makes society more legible. In other words, society is more easily read, quantified, and known to people (such as officials of the government) who do not live there. Spatial standardization makes an area comprehensible to all people, independent of local knowledge; it makes space legible beyond its immediate domain. Hence, absolute space is connected to issues of power. In Europe, standardizing and legibility-enhancing practices include a wide range of seemingly disparate phenomena, including the creation of permanent last names and population registers (Scott 1998). These practices created nonlocal, legible grids that could be read by authorities of the modern state. A modification similar to that of McCall's occurred in nineteenth-century Stockholm during its consolidation of industrial capitalism, when, according to Pred (1992), officials put up signs and numbers and attempted to standardize street names. Some linguists, historians, and geographers continue these legibility-enhancing practices by attempting to standardize place names in the name of "univocity" - that is, the eradication of the polysemous and synonymous qualities of names in order to obtain maps of pure reference (Dorion 2000; Kerfoot 2000). All of these practices are maneuvers to gain knowledge of specific places in order to improve control. Thus, the reorganization of space into a model based on an ideology of absoluteness is associated both with high modernity and with the emergence of technocratic power (Smith and Katz 1993). ${ }^{13}$

In sum, the Rural Addressing System is an example of space distanciation and a mechanism of globalization. It puts the Payette Lakes area "on the grid" with the rest of the nation, linking it systematically to places beyond its immediate borders. The social relations that are implicated in this newer system are not the local, contingent ones found in the pre-RAS period but are relations that obtain at a far more distanced and abstract level. Furthermore, the RAS can be understood as a means of technocratic control that utilizes tools commonly associated with modernity, such as rationalization and standardization. The RAS reorganizes and rationalizes local space on behalf of the state to obtain greater knowledge and control of the area, and its implementation suggests power relations directly linked to recent tourism, development, and investment interests about which many local residents are conflicted.

\section{Re-embedding and Spatial Contingency}

While it is true that the Rural Addressing System has reorganized space, to stop here is to reinforce the idea that space distanciation (and related social processes) are top- 
down hegemonic processes and that traditional discursive resources are necessarily displaced or rendered powerless in their wake. As they re-embed space in wayfinding practices, people do not necessarily use the placenames that have been implemented by local officials, or they may use them in ways that defy authorial intent. Unfortunately, scholars do not usually look at the question of which names are used and when, because placenames are rarely studied beyond their referential or etymological aspects (for critiques, see Basso 1988 and Nicolaisen 1991; see also, however, Gabbert 2000 and Harris 1989). Examining the activity of giving and receiving directions (and hence, the use of placenames) in social interaction offers a way of understanding how people re-embed space and the extent to which the RAS has affected them. In doing so, one finds the reorganization of space to be much more complex than the simple top-down imposition of a modern technocratic grid.

Because the Rural Addressing System was implemented so recently, many people in the Payette Lakes area are familiar with pre-RAS wayfinding methods, but everybody also knows what their address is. The two modes of organization exist sideby-side and constitute two differently organized discursive resources that can be drawn upon in any particular situation, providing a wide rhetorical field of wayfinding methods from which residents may actively choose. Rather than the wholesale replacement of one system with the other, what I found in my fieldwork is that people generally mix the two, creating a hybrid system. Here, individual performances exist along a continuum, with the experiential, embedded, pre-RAS system at one far end and the gridlike, disembedded system at the other. McCall residents now refer both to buildings, natural landmarks, and old homesteads, on the one hand, and to street signs and house numbers on the other; in other words, when giving directions, people logically use what makes the most sense at the time. What "makes sense," however, is intricately interconnected with issues of residential identity, and residential identity in the Payette Lakes area is a political matter. Wayfinding is used as a rhetorical tool not only to signal residential/insider status but also to frame participant relationships in particular ways, to claim power, and even to resist perceived ideological/political/economic domination. These contingencies are significant, because they directly affect and transform sociocultural processes as they are re-embedded in everyday life.

\section{Signaling Residential Status}

County Surveyor Tom Kerr is a good example of a person who is comfortable with both systems. Kerr was born in the area in 1937, and because of his age and length of residence he knows perfectly well how to get around without street signs and house numbers. As county surveyor, he was marginally involved with the implementation of RAS, and as county commissioner, he supports rural development and growth. He therefore has a wide variety of wayfinding resources at his fingertips. I asked Kerr whether he privileged one wayfinding system or the other. He was unsure, although he acknowledged the existence of the two. I asked him to give me directions to his house in order to test which system he used. He mixed landmarks, cardinal directions, and street numbers to give the location of his home: 
If you want to go to my house,

you go out the highway towards Boise

to the Mill restaurant.

And then you turn right, to go towards the high school.

Then you hit Placid [Street] on your left

and turn south on Placid

and I'm the second house on Placid.

And it's [house number deleted] Placid.

I use both [types of wayfinding methods].

I also asked Tom's wife Faye to give me directions to her house. She also mixed landmarks, street names, and numbers, but she emphasized embedded features:

Going from here you go down to the corner.

And then you turn left.

Go past The Mill.

Go to The Mill restaurant and that's Stibnite Street, going towards the high school.

You go right on that, two blocks.

Turn to your left.

And we're the second house on the right, green house. ${ }^{14}$

While Tom gave both the street he lives on and his actual house number, he left out the name of Stibnite Street and instead referred to the high school. The only official place name that Faye included was Stibnite Street; she omitted Placid Street as well as the actual house number.

The following example is from my sister, who moved to the area after the implementation of the RAS and who lives in a recently constructed duplex. In giving directions to her house, she relies on street names and numbers but also adopts features associated with a more "embedded" system.

Leave McCall like you're going to Lake Fork.

Go past Franklin Building Supply to about, I would say, one to one-and-a-half miles, there's uh, Curt's Automotive is on the right side?

And that's Heinrich Lane, turn right on Heinrich Lane.

Go down about quarter mile.

Just past the speed limit sign, there's a duplex on the right, white with brown trim and a Y-shaped driveway and our side is $28 \mathrm{~B}$.

Heinrich Lane. ${ }^{15}$

Drawn from two long-term residents and a resident who moved to McCall after RAS was implemented, these examples illustrate how people mix embedded and disembedded wayfinding practices as they re-embed space in different ways. The RAS grid has not displaced older means of spatial organization; instead, it has become flexibly incorporated, providing a broader array of information upon which people draw. 
Rather than a model of displacement, the reality is one of hybridity. This hybrid usage, however, is highly contingent upon a number of contextual features, the most obvious in these examples being participant identity based on length of residence. My sister initially learned the RAS because of her newcomer status, but she has incorporated more experiential features over time, signaling her changing identity as resident rather than visitor or newcomer. In contrast, Faye's description is primarily embedded, signaling her identity as a long-term resident. To a certain extent, then, one's residential identity determines one's spatial knowledge, and conversely, the means one uses to organize space is based on — and signals — one's identity as a longterm local or visitor or newcomer. In the Payette Lakes area, residential identity is a key political feature. Categories of old-timer, newcomer, and visitor/tourist have always been a means of sorting people out. But these categories have become more emphasized with the recent changes, even as distinctions of who actually is a newcomer or an old-timer have become less clear. Wayfinding, then, is a means of establishing oneself as an insider and one way of distinguishing "who's who," a function explored in further detail below.

Conversely, participant identities also jointly construct space. Sheila, who doesn't know the names of streets, framed wayfinding practices as a kind of language, what scholars of discourse call "code-switching." Taking both sides in a mock conversation, she explained it this way:

So it's like in a way there is a certain language deal, because I don't know the new names.

And so to get that name...

it's like I have to translate into a different language to get to the third language ....

I have to go the old-what I knew.

It's like, "I don't know where Forest Street is, but is it anywhere by the Chevron station?"

"Well, yeah, it's by the Chevron,".... - [or] "No, it's not."

"You know where the old-the road to the school is?" "Yeah."

"OK, you know the old Forest Service building that's abandoned now?"

"Yeah, I know that."

So then you go from that.

You say, "OK, I know those two things."

"So then Forest Street is right in front of it, it's that one that runs from here to the Star-News, to the Congregational Church."

"Oh, that's Forest Street."

So I have to go through an intermediary language, whatever, point, reference to get to what most people now just go,

"Oh, it's Forest Street."

In this narrative, Sheila explains that she has to get to a "place" that she knows in order to translate the names into her own "language" and to understand where they 
(she and her interlocutor) are. Where are we now and where do we need to go? These terms must be understood by both parties in order for a wayfinding exchange to occur, suggesting a mutually constitutive relation between identity and the organization of space in discourse that is grounded in and emerges from talk about the landscape. "Place" in this sense is communicatively grounded and emergent (Basso 1996; Bauman 1986).

\section{Framing Participant Relationships}

Since identity varies and is flexibly constituted, which identity features are highlighted in a given situation further complicates the picture, suggesting that wayfinding can be used to stake claims about identity and the nature of participant relationships. As Tom Kerr explains, "To me, it's [about] giving clear information to people that they [can] understand," illustrating that which identity features are highlighted depends also on audience. He elaborates with several instructive hypothetical examples: "If a surveyor comes in here and wants to know something, I'll give him Township, Range, and Quarter system. That's the way his mind works. It's a different system." In this example, Kerr's hypothetical interlocutor is a surveyor, and using the surveyor's system for describing place, he highlights his identity as a surveyor and he frames the interaction as one specialist speaking to another. Clearly, direction giving is based on the identities of both the speaker and the listener, since communication is co-achieved (Dolby-Stahl 1989; Duranti 1986). Identity and the re-embedding of space are intimately interconnected in ways that are hidden if one only looks at the imposition of the county- and city-mandated systems, which suppose "identity-free" principles.

In another hypothetical example, Kerr frames his relationship as old-timer to oldtimer: "Say I was telling Jayne Brown where the drive-in is going to be? Well, it's Burt and Esther Brewster's old house. She knows exactly where that is. If I told her it was 1148 Boydstun, she wouldn't know where that is." A primary identity feature for Jayne Brown is that she is a long-term, respected resident of the area. Kerr acknowledges this fact by referring to "Burt and Ether Brewster's old house" rather than to 1148 Boydstun Street. This choice signals not only his recognition of who Brown is but also an understanding of who he is in relation to her; he positions himself as a person who knew the Brewsters personally and who "understands" Jayne Brown as someone who also knew them. His salient identity feature is not, in this instance, that of a surveyor. Rather, he is staking a claim about the nature of his relationship to Jayne Brown, as one old-timer speaking to and recognizing the other as such; he is signaling his status as an insider in relation to her status.

These examples illustrate that wayfinding is a metadiscursive practice (Basso 1988), a communicative process in which messages are exchanged about the meaning of the ongoing social interaction (Leslie and Skipper 1990). Wayfinding does not merely "reflect" speaker/listener identities; at least temporarily and if only within the context of a particular interaction, wayfinding constructs those identities by staking claims about the actual social situation and people who are involved. Kerr does choose a particular wayfinding method based on his own identity and that of the listener, but 
more importantly, he signals his perception of his own relationship to that person through specific wayfinding strategies.

To further illustrate the relationship between wayfinding strategies and claims about participant relationships, the example below demonstrates a way of organizing space independent of the RAS system. Surveyor Dave Harold gives directions to his old house in Lake Fork to surveyor Rob Skipton. Both men are very familiar with the region and have lived here a long time:

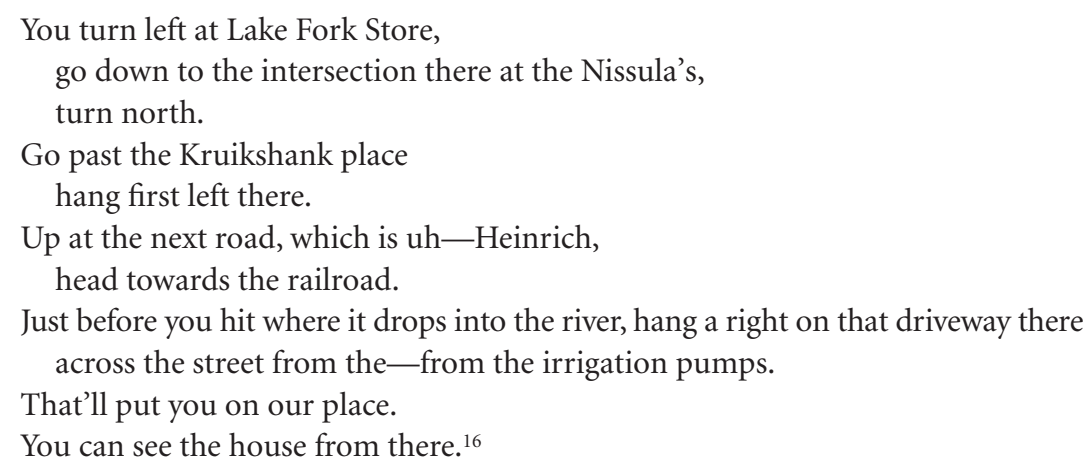

This exchange is almost entirely embedded in locale. In choosing this embedded wayfinding method, Dave's directions speak to participant identities and the relationship of those identities to each other. Dave acknowledges himself as a long-term resident, acknowledges Rob as a long-term resident, and through his choices purposefully frames their interaction as a mutually agreed-upon understanding of people who recognize the other as a long-term community member. The choice of discursive resources used in wayfinding situations therefore directly depends on the identities of both participants and the kinds of claims being made on the relationship that participants have with each other.

\section{Power, Ideology, Resistance}

Because wayfinding signals identity, perceptions about identity, and claims about the nature of identity relationships, wayfinding can be used not only consciously but also strategically, ideologically, and politically (Julyan 2000; Nicolaisen 1990; Roberts 1993). Silverstein and Urban note that "individuals acquire, and have inculcated in them, not only specific entextualization practices [i.e., the process of rendering a stretch of reality as a textual and isolatable unit], but also metadiscourses or ideologies about texts through which they assess their own practices in both interpretive and strategic stances" (1996:10). In other words, not only do people speak in particular ways, but they also have ideas about and place value on certain ways of speaking or other discursive practices. In his Apache research, Keith Basso, for example, emphasizes that "placename talk" entails "morally guided assessments ... of fellow participants" and that the Apache are aware of their own linguistic and place name ideology: the Apache can explain to others what spoken words are capable of doing when used in certain ways $(1988: 101,107,115)$. Relatedly, in the Payette Lakes area, 
people have ideas about giving directions and ascribe values to the kinds of place names they use. They assess other people according to the way in which directions are given, and they may place value on one wayfinding method over another.

One interesting result of the implementation of the Rural Addressing System in the Payette Lakes area is that it has recontextualized older, embedded wayfinding methods, thus creating new meanings for them that were not previously there. In situations where locals predominate, status - and therefore power-in the Payette Lakes area is derived in great part from one's length of residence and from how many people one knows. While money counts here, it is not the only marker of status. Therefore, these days the ability to use "embedded" pre-RAS wayfinding methods signals not only an old-timer identity but also one that has status and power. Consider Sheila's example:

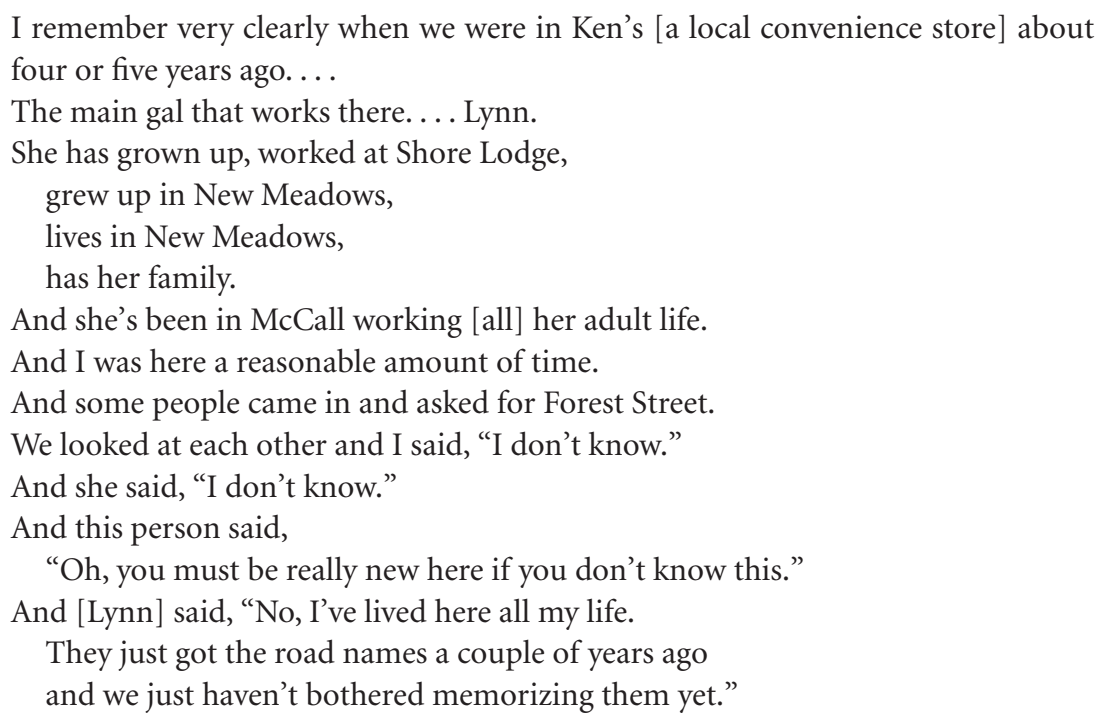

In this narrative, the direction receiver interpreted the narrator's inability to answer the question as it was phrased as an inability to organize space at all—a total lack of knowledge about the area. Since local status is related to length of time lived in the area, the narrator interpreted the comment of "you must be new here" as a slight. The response- that she and Lynn had lived here for a long time and this was in fact the reason why they didn't know the street names-quickly reframed the relationship in order to reestablish their status as long-term residents and to set them apart from newcomers. This kind of one-upmanship is common in rural environments. Wayfinding here was used to stake a claim to power, because the use of older, embedded wayfinding practices signifies that the speaker has been in the area a long time. The use of abstract, experience-free wayfinding methods based on street signs does not, and this was clearly explained to the addressee in order to correct the misinterpretation. ${ }^{17}$ The RAS has provided an opportunity for people to assume ideological stances toward particular wayfinding methods. It has recontextualized the use of the preRAS system, providing new contexts for meaning not previously there. 
Furthermore, the line "we just haven't bothered memorizing them yet" suggests a stance of resistance-a conscious decision to disregard the new, "official" system and to intentionally use the old one, at least for the time being. Pred (1992) interprets the purposeful disuse of official place names as a sign of symbolic discontent and resistance to ideological domination, an interpretation that applies here as well. Pred, however, locates the source of discontent primarily in lower- and working-class displeasure, while in this case the opposite seems true. Sheila is middle class and has a relatively high-status position within the community, a position that she stakes through her wayfinding choices but that in reality is threatened somewhat by the recent socioeconomic change. This type of symbolic resistance is what de Certeau (1984) identifies as a "tactic," tiny practices of everyday resistance that are normally overlooked by large structures of domination because they differ so greatly from overt, obvious forms of resistance such as revolution or street protest. Rather, for de Certeau - and for many folklorists_-it is in the minutia of life, such as wayfinding, that one discovers acts of opposition; indeed, de Certeau draws on many folkloric examples in his work. Thus the modernization of wayfinding practices can actually increase the use of traditional ones through the generation of new meanings, providing new reasons and opportunities for use. The use of wayfinding as a form of resistance is possible only within the context of the RAS system. It is within this new context that an unfamiliarity with RAS can retroactively become privileged, illustrating that modernizing processes may contain within themselves the seeds of their own reversal and hence that they are never fully complete. More specifically, it illustrates exactly why in this case "the local" might become more-not less-important in contexts of social change.

Both old-timers and newcomers as well as those across the political spectrum can use wayfinding as a rhetorical tool in struggles for status and power. Sheila provided another example of this strategic use of discourse resources. In this case, a newcomer invented insider status for himself in order to boost his own authority for financial gain. Her example was based on a social code that functions in a manner similar to wayfinding cues. Sheila explained that even if she doesn't know someone directly, she is able to figure out quickly who they are by determining if they use a particular "code." This code, which was her word for it, consists mostly of memories of people, what Barbara Allen, in discussing the sense of place in the American South, describes as "personal and generational memories and the accretion of myriad concrete details about the lives of their neighbors, both past and present, gained in lifetimes of observations, interactions, and conversations" (1990:153-4). Sheila says:

You could speak of certain words, you had certain cue words that could tie into ten years twenty years, whatever, or before.

So you knew where you were within thatit's like creating your own niche, or your own status:

telling them where you stand, where you are-I mean it's interestinghow long you've been here. 


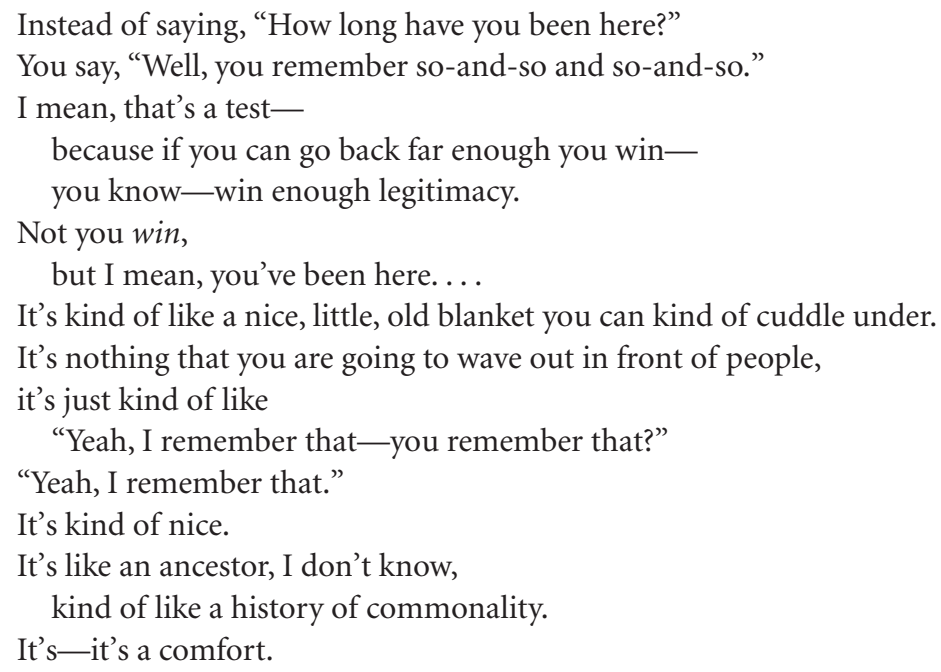

Since it is highly embedded, what Sheila describes is not a code that can be neatly mapped. The organizing principles of this code, however, parallel pre-RAS wayfinding methods, because they are derived from local experience, knowledge of people, and historical memory. Thus, these socially based organizing principles and the hierarchical ideologies associated with them permeate how people in this area communicate in ways that extend well beyond mere wayfinding.

Although the existence of this code was obvious to Sheila at the time of our interview, she had only recently become consciously aware of it. It came into focus when she met a real estate agent. Sheila found the man slightly distasteful but couldn't understand why until a friend of hers figured it out. An outsider/newcomer, the real estate agent recognized the advantages of embedded local knowledge and appropriated it for his own personal financial benefit. Sheila recalls:

It was in the nature of his business.

He was-he's kind of slick.

And he kind of wanted to fit in real well because in his business,

it made a lot of sense for him to look like he knew the old, the old farms, the old businesses.

The old McCall.

And so anyway ... I would talk and this guy would pull up names.

Fairbrothers, the old ranch out there on the side that a lot of people don't know about....

And I thought,

"How did he know?"

He hasn't—he couldn't have been here [then], I know.

And then ... [the friend] I think said it, "They know the right words Sheila.

They've learned the cue.

They've broken the code." 
And I went,

"That's what he did."

He was able to learn all these old words,

all the old family names,

or all the cues

that we would give back and forth that we knew.

He had absorbed them, he had learned them

-he'd broken the code.

He hadn't experienced them, he had no knowledge of them.

But he knew them.

He knew how to hand them out

and to make them believe.

She continues:

... it blew me away.

I realized suddenly that that's what we had been using.

No matter what, you didn't-you weren't overt and said,

"How many years have you been here?"

You know, "What legitimacy do you have here?"

Or, "How far back do you go here?"

Everybody else thought that he was speaking their same language.

It also loosened up the real estate.

It made it more approachable for other old people to go,

"Well, oh, you know so-and-so!"

$\mathrm{He}$ [real estate agent] was a great guy,

but it opens up a lot of interesting avenues in trust

-believability, trust; trust and everything....

That's what bothered me about [the real estate agent].

I knew he wasn't there.

I knew he was slick

and I knew that he could use it, not in the fairest way.

He could cheat with it. He could cheat with it.

And it was meant to be-

a kind of a certain trustworthiness there

and he knew how to cheat with it.

Because this embedded code is an emic way to signal status, the real estate agent appropriated it, creating a "fabricated place" by giving out social cues of which he had no experiential knowledge in order to sell property. He manipulated other people's (potential clients') perceptions of his identity, falsely framing the relationship that obtained between him and them in order to claim status and power. From the real estate agent's point of view, however, this act might also be considered as one of resistance to a closed old-boy system. As a newcomer, he may not have had enough status to sell property, and the appropriation of local codes to further his own interests can be interpreted as a struggle against local elite authority. Of course, this "resistance" also exists within the larger context of globalization and the power of capital from external development. At 
any rate, his (mis)appropriation of this code for his own benefit illustrates how powerful and important expressive resources are; in this case, traditionalized ones have become even more important within the context of modernization, and they can be used by all sides as rhetorical weapons in struggles for power.

\section{Conclusions}

Interrelated with processes of social control associated with modernization, globalization, and socioeconomic change in the Payette Lakes area, the Rural Addressing System is a contemporary example of a mechanism that disembeds space. Yet space distanciation is not simple or straightforwardly implemented; rather, it is incomplete, complex, and context-dependent. As space becomes re-embedded in new ways, the Rural Addressing System has opened up a realm of possibilities for wayfinding from which people may choose. Mostly, people mix embedded and disembedded orders of information depending on the situation; the result is an organization of space that is neither embedded nor distanciated but rather a kind of hybrid.

The specific way in which these orders of information are mixed is complex. Placenames and wayfinding in general function on a variety of levels, only one of which is referential (Jakobson [1935] 1971). Due to their metadiscursive nature, wayfinding choices depend on how participants understand the identity features of a given situation and on the ways in which they wish to stake claims on and about social relationships. Further, the Rural Addressing System has recontextualized older ways of organizing space, and new, ideologically based meanings emerge that were not previously there. In the Payette Lakes area, wayfinding is connected to claims about insider status and hence is interrelated with broader issues of politics and change. People use wayfinding and other traditional forms of communication to distinguish themselves from newcomers, to claim status and power, to create a means of resistance, or even to make false claims about who they are. These new meanings, grounded in new situated contexts, allow for the continued, purposeful use of traditional organizational means. Constituted in wayfinding, space, place, and locality are not "out there" as objects to be described in words but are context-dependant, relational, and ideological.

These findings make clear that the globalization of modernity must be investigated ethnographically and comparatively. The organization of space certainly has been modernized in the Payette Lakes area by officials for purposes of efficiency and control, but its implementation and use is not clear-cut; it is obvious that people choose wayfinding strategies for their own purposes. Further, space distanciation is not a thing of the past associated only with premodern societies, but rather is currently happening in a modern society such as the United States. Although sparsely populated and remote, the Payette Lakes area is a contemporary community with television, a postindustrial economy, Internet access, and modern transportation. Yet in other ways, the Payette Lakes area is very much not modern. This makes it an appealing place for thinking about issues of modernization and globalization, and in the end studies such as this one can yield a more multifaceted picture of the nature of social and cultural change. 


\section{Notes}

Research for this article was supported partially by a New Faculty Research Grant from Utah State University. I am indebted to Sandy Dolby and Richard Bauman for many conversations in which these ideas developed, and to Jan Roush, Steve Siporin, the current JAF editors, and the two anonymous reviewers of this article for their help, encouragement, and critical suggestions. I also owe a debt of thanks to my working group at the "Outside American Studies" Institute at Dartmouth College, who provided feedback on some early musings in June 2002.

1. When I use RAS as an abbreviation for the Rural Addressing System, I am referring specifically to Valley County's Rural Addressing Ordinance and the City of McCall's Ordinance 660.

2. Giddens's work is only one of many theories of globalization, and it is often criticized as offering a rather Eurocentric viewpoint. Others, for example, see globalization as a very old and deeply rooted process. For alternative theories, see Pieterse (2004).

3. Doug Manchester, CEO of Manchester Resorts, was the first large, out-of-state developer to take interest in the area. Known for his controversial business style, Manchester has investments including high-rise industrial buildings, office parks, golf courses, and resorts across the county; he has played a particularly prominent role in developing downtown San Diego by building Marriott and Hyatt hotels along the bayfront area. He purchased McCall's Shore Lodge in 1988. During this same period, the agricultural economy of the Payette Lakes area, and of the state of Idaho as a whole, began to shift. Between 1987 and 1991, for example, Idaho's nonagricultural wage and salary employment soared 27.5 percent, the fastest rate of all fifty states (Altork 1994). In terms of development, there were 2,559 new structures built in Valley County during the 1990s, as compared to 1,464 new structures during the previous decade (Idaho Department of Commerce and Labor n.d.b).

4. In 1990, the median value of owner-occupied housing in the city of McCall was \$66,500; by 2000, this jumped to $\$ 151,300$ (Idaho Department of Commerce and Labor n.d.a). The Star-News reported in June 2005 that the value of property across Valley County rose an additional 36 percent when compared to 2004, largely due to the completion of Tamarack ski resort (Salmon 2005a). Studies of affordable housing conducted in 2005 concluded that approximately 87 percent of full-time residents would need some form of assistance to buy a home at current prices (Salmon 2005b).

5. Claude Levi-Straus's brand of structuralism in the 1960s attempted to de-emphasize time, so in this sense the roots of this movement date further back than the 1980s, although even this de-emphasis amounts to a kind of attention to time.

6. I use the term "space" in its most conventional sense, since I am interested here in the ways in which people orient themselves in the world. I am not using the term "space" to signify a "void of meaning," which is one way space is commonly distinguished from place.

7. According to County Surveyor Tom Kerr, before RAS even mail delivered along the rural routes depended on personal knowledge. The mailman, he says, just knew where everybody lived. Illustrating the point, he told me the following story: "When I went to college in the mid-50s, I would send a letter to 'Sue' [his mother] in McCall. Not even a last name; just 'Sue' in McCall. And it would get to McCall. ... That has changed. Now, about the only mail I get that is sent to me without an address is if it's to me as a commissioner. And then it depends on who is sorting the mail at the post office ... if they know me or not. Me or Faye [Kerr, his wife].”

8. The name Sheila is a pseudonym. All of the quotations from her in this article are taken from an interview with author, conducted in McCall, Idaho, February 27, 2001.

9. To make block quotations easier to read, I have developed my own system of transcription. My approach is influenced by Henry Glassie (1982), although my own transcriptions are not intended as his "rendered poetics." In all cases, each new sentence begins with a new line in the transcription. A pause within a sentence is indicated by a new indented line, and a second pause in the same sentence is indicated by two indentations. Further, ellipses indicate that words have been deleted and hyphens indicate a long verbal pause. Emphasis in the speaker's tone of voice is indicated with italics; my emphasis is indicated with underlines. 
10. It is nearly impossible to establish a date for this ordinance. According to McCall city council minutes, an ordinance regarding house numbers was adopted in 1975; apparently, it was not enforced because it was difficult for residents to comply with the requirement that house numbers be visible from the street. By 1984, McCall still lacked street signs. The city crew apparently did not have time to install them, and Mayor Clyde L. Archer suggested that perhaps a local service organization might do it. That year he also ordered the police chief to enforce the house numbering ordinance, an order that was repeated in 1985. In 1986 street signs still had not been installed, and an estimate was given that they would cost the city approximately $\$ 6,000.00$. A proposal was made to include this as part of the 1987 budget, or, alternatively to install street signs partially over the next few years in order to accommodate the cost. (Taken from McCall City Council minutes, August 5, 1974; January 7, 1975; April 7, 1975; July 16, 1984; September 5, 1985; June 2, 1986.)

11. In using the term "abstract," I do not mean to suggest that the older system was somehow less sophisticated or complex. By this term I simply mean to suggest that the RAS is less concrete and more removed from everyday experience.

12. The term "grid" is more metaphorical than literal. That is, the streets of McCall are not laid out in a literal grid consisting of X-Y axes. Rather, the notion of grid is used to mean a conception of space upon which exact coordinates are mapped. The idea of being "off the electrical grid," for example, refers to an area that does not have regular electrical service distributed by a power company, not to the physical configuration of power lines. Further, even in areas off the electrical grid, particular homes might have a generator for their own use. In this sense, until the Rural Addressing System was implemented, the McCall area was off the house-and-number "grid."

13. Henri Lefebvre has argued that it is a conception of space appropriate for a project of social domination (quoted in Smith and Katz 1993).

14. Both Tom and Faye Kerr were interviewed by the author, McCall, Idaho, July 8, 2005.

15. Interview by author, McCall, Idaho, July 10, 2005.

16. Interview by author, McCall, Idaho, July 8, 2005.

17. That that status needed to be explained is in itself interesting. Tom Kerr agreed that the ability to speak in this manner signals status, but he added, "there's no sense in using a status symbol if the person you're talking to doesn't know what you are talking about.”

\section{References Cited}

Allen, Barbara. 1990. The Genealogical Landscape and the Southern Sense of Place. In Sense of Place: American Regional Cultures, ed. Barbara Allan and Thomas J. Schlereth, pp. 152-63. Lexington: University Press of Kentucky.

Allen, Barbara, and Thomas J. Schlereth, eds. 1990. Sense of Place: American Regional Cultures. Lexington: University Press of Kentucky.

Altman, Irwin, and Setha M. Low, eds. 1992. Place Attachment. New York: Plenum.

Altork, Kathleen. 1994. Land Running through the Bones: An Ethnography of Place. Ph.D. diss., The Union Institute.

Appadurai, Arjun. 1986. Theory in Anthropology: Center and Periphery. Comparative Studies in Society and History 28(2):357-61.

1988a. Introduction: Place and Voice in Anthropological Theory. Cultural Anthropology 3(1):1620.

1988b. Putting Hierarchy in Its Place. Cultural Anthropology 3(1):36-49.

1996. Modernity at Large: Cultural Dimensions of Globalization. Minneapolis: University of Minnesota Press.

Basso, Keith H. 1988. "Speaking with Names”: Language and Landscape among the Western Apache. Cultural Anthropology 3(2):99-129.

1996. Wisdom Sits in Places: Notes on a Western Apache Landscape. In Senses of Place, ed. Steven Feld and Keith H. Basso, pp. 53-90. Albuquerque: University of New Mexico Press. 
Bauman, Richard. 1986. Story, Performance, and Event: Contextual Studies of Oral Narrative. Cambridge: Cambridge University Press.

Bestor, Theodore C. 2003. Markets and Places: Tokyo and the Global Tuna Trade. In The Anthropology of Space and Place: Locating Culture, ed. Setha M. Low and Denise Lawrence-Zúñiga, pp. 301-20. Oxford: Blackwell.

de Certeau, Michel. 1984. The Practice of Everyday Life, trans. Steven Rendall. Berkeley: University of California Press.

Cottrell, Sandra, and Beverly Ingraham. 1987. Long Valley Yesterdays. Bend, Ore.: Maverick.

Del Negro, Giovanna P. 2004. The Passeggiata and Popular Culture in an Italian Town. Montreal: McGillQueen's University Press.

Dolby-Stahl, Sandra. 1989. Literary Folkloristics and the Personal Narrative. Bloomington: Indiana University Press.

Dorion, Henri. 2000. Should All Unofficial Placenames Be Eliminated? Names 48(3-4):249-55.

Duranti, Alessandro. 1986. The Audience as Co-Author: An Introduction. Text 6(3):239-47.

Eisenstadt, S. N. 2000. Multiple Modernities. Daedalus 129(1):1-129.

Fabian, Johannes. 1983. Time and the Other: How Anthropology Makes Its Object. New York: Columbia University Press.

Feld, Stephen, and Keith H. Basso, eds. 1996. Senses of Place. Santa Fe: School of American Research Press.

Foster, Robert J. 2002. Bargains with Modernity in Papua New Guinea and Elsewhere. Anthropological Theory 2(2):233-51.

Foucault, Michel. [1977] 1995. Discipline and Punish: The Birth of the Prison. 2d ed. New York: Vintage.

Frykman, Jonas, and Orvar Löfgren. 1987. Culture Builders: A Historical Anthropology of Middle-Class Life, trans. Alan Crozier. New Brunswick, N.J.: Rutgers University Press.

Gabbert, Lisa. 2000. Naming Places: Re-Shaping and Re-Modeling through Local Linguistic Practices. Midwestern Folklore 26(2):5-10.

Gaffin, Dennis. 1994. The Geographic Identities of Faeroe Islanders. Landscape 32(2):20-7.

Giddens, Anthony. 1990. The Consequences of Modernity. Stanford, Calif.: Stanford University Press.

Glassie, Henry. 1982. Passing the Time in Ballymenone: Culture and History of an Ulster Community. Philadelphia: University of Pennsylvania Press.

Göle, Nilüfer. 2000. Snapshots of Islamic Modernities. Daedalus 129(1):91-117.

Gupta, Akhil, and James Ferguson, eds. 1997. Culture, Power, Place: Explorations in Critical Anthropology. Durham, N.C.: Duke University Press.

Hall, Stuart, David Held, Don Hubert, and Kenneth Thompson. 1996. Modernity: An Introduction to Modern Societies. Oxford: Blackwell.

Halpert, Herbert. 1947. American Regional Folklore. Journal of American Folklore 60(238):355-66.

Haraway, Donna. [1997] 2002. The Persistence of Vision. In The Visual Culture Reader, ed. Nicholas Mirzoeff, pp. 677-84. London: Routledge.

Harris, Marion O. 1989. New St. Gets a Name. Names 37(4):305-15.

Harvey, David. 1990. The Condition of Postmodernity. Oxford: Blackwell.

Heelas, Paul, Scott Lash, and Paul Morris, eds. 1996. Detraditionalization. Oxford: Blackwell.

Heer, Cheryl Temple. 1996. Critical Regionalism and Cultural Studies: From Ireland to the American Midwest. Gainesville: University Press of Florida.

Hufford, Mary. 2002. Interrupting the Monologue: Folklore, Ethnography and Critical Regionalism. Journal of Appalachian Studies 8(1):62-78.

Idaho Department of Commerce and Labor. n.d.a. Idaho Community Profiles, McCall. http://community.idaho.gov/Profiles/tabid/440/Default.aspx, accessed January 20, 2007.

- n.d.b. County Profiles of Idaho, Valley County. n.URL.

Jakobson, Roman. [1935] 1971. The Dominant. In Readings in Russian Poetics: Formalist and Structuralist Views, ed. Ladislav Matejka and Krystyna Pomorska, pp. 82-7. Cambridge, Mass.: MIT Press.

Johnstone, Barbara. 1990. Stories, Community, and Place: Narratives from Middle America. Bloomington: Indiana University Press. 
Jordan, Grace Edgington. 1961. The King's Pines of Idaho: A Story of the Browns of McCall. Portland, Ore.: Binfords \& Mort.

Julyan, Robert. 2000. Protecting the Endangered Blank Spots on Maps: The Wilderness Names Policy of the United States Board on Geographic Names. Names 48(3-4):217-26.

Kaplan, Amy, and Donald E. Pease, eds. 1993. Cultures of United States Imperialism. Durham, N.C.: Duke University Press.

Kaviraj, Sudipta. 2000. Modernity and Politics in India. Daedalus 129(1):137-61.

Kerfoot, Helen. 2000. United States and Canada: Partners in Geographic Names Standardization. Names 48(3-4):243-8.

Knauft, Bruce M., ed. 2002. Critically Modern: Alternatives, Alterities, Anthropologies. Bloomington: Indiana University Press.

Lefebvre, Henri. 1976. Reflections on the Politics of Space, trans. Michael J. Enders. Antipode 8(2):30-7.

- 1991. The Production of Space, trans. Donald Nicholson-Smith. Oxford: Blackwell.

Leslie, Paul L., and James K. Skipper. 1990. Toward a Theory of Nicknames: A Case for Socio-Onomastics. Names 38(4):273-82.

Low, Setha M., and Denise Lawrence-Zúñiga, eds. 2003. The Anthropology of Space and Place: Locating Culture. Oxford: Blackwell.

Massey, Doreen. 1994. Space, Place, and Gender. Minneapolis: University of Minneapolis Press.

McDowell, Linda. 1999. Gender, Identity, and Place: Understanding Feminist Geographies. Minneapolis: University of Minnesota Press.

Nicolaisen, W. F. H. 1990. Placenames and Politics. Names 38(3):193-205. . 1991. Onomastics_-An Independent Discipline? In The Study of Names, ed. Ronald L. Baker, pp. 9-22. Terre Haute: Indiana Council of Teachers of English and the Hoosier Folklore Society.

Norkunas, Martha K. 1993. The Politics of Public Memory: Tourism, History, and Ethnicity in Monterey, California. Albany: State University of New York Press.

Pieterse, Jan Nederveen. 2004. Globalization \& Culture: Global Mélange. Lanham, Md.: Rowman \& Littlefield.

Pred, Allan. 1992. Languages of Everyday Practice and Resistance: Stockholm at the End of the Nineteenth Century. In Reworking Modernity: Capitalisms and Symbolic Discontent, ed. Allan Pred and Michael John Watts, pp. 118-54. New Brunswick, N.J.: Rutgers University Press.

Radway, Janice. 1999. "What's in a Name?" Presidential Address to the American Studies Association, November 20, 1998. American Quarterly 51(1):1-32.

Roberts, J. Timmons. 1993. Power and Placenames: A Case Study from the Contemporary Amazon Frontier. Names 41(3):159-81.

Robertson, Roland. 1995. Glocalization: Time-Space and Homogeneity-Heterogeneity. In Global Modernities, ed. Mike Featherstone, Scott Lash, and Roland Robertson, pp. 25-44. London: Sage.

Robins, Kevin. 2003. Encountering Globalization. In The Global Transformations Reader, ed. David Held and Anthony McGrew, pp. 239-45. 2d ed. Cambridge: Polity Press.

Robinson, William I. 2003. The Debate on Globalization. Science and Society 67(3):353-60.

Ryden, Kent. 1993. Mapping the Invisible Landscape: Folklore, Writing, and the Sense of Place. Iowa City: University of Iowa Press.

Salmon, Ben. 2005a. Value of Many Valley Parcels to Increase Again. Star-News, June 30, 2005. . 2005b. Development Ban Extended to Impact Area Around McCall. Star-News, July 21, 2005.

Scholte, Jan Aart. 2000. Globalization: A Critical Introduction. Basingstoke, England: Palgrave.

Scott, James C. 1998. Seeing Like a State: How Certain Schemes to Improve the Human Condition Have Failed. New Haven, Conn.: Yale University Press.

Shuman, Amy, and Charles L. Briggs, eds. 1993. Theorizing Folklore: Toward New Perspectives on the Politics of Culture. Special issue, Western Folklore 52(2-4).

Silverstein, Michael, and Greg Urban, eds. 1996. Natural Histories of Discourse. Chicago: University of Chicago Press.

Smith, Neil, and Cindi Katz. 1993. Grounding Metaphor: Towards a Spatialized Politics. In Place and the Politics of Identity, ed. Michael Keith and Steve Pile, pp. 67-83. London: Routledge. 
Soja, Edward W. 1989. Postmodern Geographies: The Reassertion of Space in Critical Social Theory. London: Verso.

Steubner, Steve. 2006. Valley County, Idaho. Skywest Magazine, January/February, 24-30.

Thrift, Nigel. 2000. "Entanglements of Power: Shadows?” In Entanglements of Power: Geographies of Domination/Resistance, ed. Joanne P. Sharp, Paul Routledge, Chris Philo, and Ronan Paddison, pp. 269-78. London: Routledge.

Tomlinson, John. 1999. Globalization and Culture. Chicago: University of Chicago Press.

. 2003. Globalization and Cultural Identity. In The Global Transformations Reader: An Introduction to the Globalization Debate, ed. David Held and Anthony McGrew, pp. 269-77. 2d ed. Cambridge: Polity Press.

Tuan, Yi-Fu. 1974. Topophilia: A Study of Environmental Perceptions, Attitudes, and Values. Englewood Cliffs, N.J.: Prentice-Hall. Press.

Wilson, William. 2000. A Sense of Place or a Sense of Self: Personal Narratives and the Construction of Personal and Regional Identity. Southern Folklore 57(1):3-11. 